\title{
COMPARISON OF THE RESULTS OF ALLOY 625 CLADDING WITH TWO SHIELDING GASES IN BOILER PRODUCTION
}

\section{USPOREDBA REZULTATA NAVARIVANJA LEGURE TIPA 625 S DVA RAZLIČITA ZAŠTITNA PLINA U KOTLOGRADNJI}

\section{Originalni naučni rad / Original scientific paper UDK / UDC:}

\section{Rad primljen / Paper received:}

Jun 2014.

Rad je u izvornom obliku objavljen u Zborniku sa savetovanja „ZAVARIVANJE 2014“ održanog na Borskom jezeru 4-7. Juna 2014, gde je i izlagan.

Kljucne riječi: navarivanje, mješavine plinova, kotlogradnja,otpornost na koroziju

\section{Sažetak}

$U$ radu se opisuje navarivanje membranskih cijevnih zidova i navarivanje pojedinačnih cijevi otvora u zaštiti dvokomponentne mješavine plinova i usporedba rezultata navarivanja s rezultatima navarivanja u zaštiti četverokomponentne mješavine plinova. Navarivanje je vršeno na tri stroja za navarivanje u različitim položajima zavarivanja.

\section{Uvod}

Cilj navarivanja u zaštiti dvokomponente mešavine gasova je smanjenje troškova navarivanja, gde je najveći izdatak za helijum kao inertni gas. Visoka cena četvorokomponentnog gasa $\left(\mathrm{Ar}+\mathrm{He}+\mathrm{H}_{2}+\right.$ $\mathrm{CO}_{2}$ ), posebno helijuma, uslovila je pokušaj navarivanja u zaštiti dvokomponentnog gasa (97,5\% Ar +2,5\% CO2). Korišćeni dodatni materijal je S Ni 6625. Usled zahteva za minimum $5 \%$ Fe na površini navara, neophodno je obezbediti minimalno mešanje osnove i dodatnih materijala, ali ipak osigurati dobro vezivanje da se spreči nalepljivanje. Probno zavarivanje je izvedeno uz pomoć tri mašine za navarivanje, mašine za vertikalno navarivanje membranskih zidova, horizontalne robotizovane linije za navarivanje membranskih zidova i mašine za navarivanje pojedinačnih cevi I zaglavlja u cilju osiguranja pouzdanosti rezultata zavisno od mašine I položaja zavarivanja.

\author{
Adresa autora / Author's address: \\ 1.Đuro Đaković, TEP, d.o.o., Slav. Brod, Hrvatska; \\ bozo.despotovic@ddtep.power-m.hr \\ 2.Đuro Đaković, TEP, d.o.o., Slav. Brod, Hrvatska; \\ dalibor.zubrinic@ddtep.power-m.hr \\ 3.Strojarski fakultet, Slav. Brod, Hrvatska; Ivan.Samardzic@sfsb.hr
}

Key words: cladding, gas mixtures, steamboiler production, resistance to corrosion

\section{Abstract}

This paper describes the cladding of membrane tube walls and cladding of single tubes for window openings in two-component gas mixtures protection. Obtained results are compared with the results of cladding in four-component gas mixtures protection. Cladding was performed on three machines for cladding in different positions

\section{Introduction}

The goal of cladding in the protection of twocomponent gas is to reduce the cost of cladding, the main measure of inert gas helium. Given the high price of four-component gas $\left(\mathrm{Ar}+\mathrm{He}+\mathrm{H}_{2}+\right.$ $\mathrm{CO}_{2}$ ), helium exclusively, accessed the trial of cladding in the protection of the two-component gas $(97,5 \% \mathrm{Ar}+2,5 \% \mathrm{CO} 2)$. Additional material used for surfacing is $\mathrm{S} N \mathrm{Ni} 6625$. Due to the requirements of a minimum $5 \%$ of $\mathrm{Fe}$ on the surface of cladding, it is necessary to ensure minimum interference basic and supplementary materials, and yet achieve sufficient bonding to avoid sticking. Test welding was performed by three cladding machines, machine for vertical cladding of membrane walls, horizontal robotic line for cladding of membrane walls and a machine for single tubes and headers cladding, in order to prove the reliability of the results depending on the machine and welding position. 


\section{Optimizacija vertikalnog navarivanja}

Navarivanje je izvedeno pomoću vertikalne mašine za navarivanje membranskih zidova. Uzorak za navarivanje je membranska cev prečnika $\varnothing 57 \mathrm{x}$ 5,6 , razmak između cevi $81 \mathrm{~mm}$, od osnovnog materijala kvaliteta 16Mo3, sa dodatnim materijalom Sandvik Sanicro 60, ERNiCrMo-3, GNi6625, šarža broj 155761.

Početna tačka navarivanja su parametri zavarivanja za četvorokomponentni gas. Na slici 1 je prikazana redosled nanošenja navara na membransku cev u vertikalnom položaju

\section{Optimization of the vertical cladding}

Cladding was performed by a vertical machine for cladding membrane tube walls. Cladding sample is the membrane wall pipe diameter $\varnothing 57 \times 5,6$, peach between the tube $81 \mathrm{~mm}$, quality basic material 16Mo3, with additional material Sandvik Sanicro 60, ERNiCrMo-3, GNi6625, batch 155761.

The starting point of cladding is welding parameters for four-component gas. Figure 1 shows the sequence of the cladding membrane walls in the vertical position.

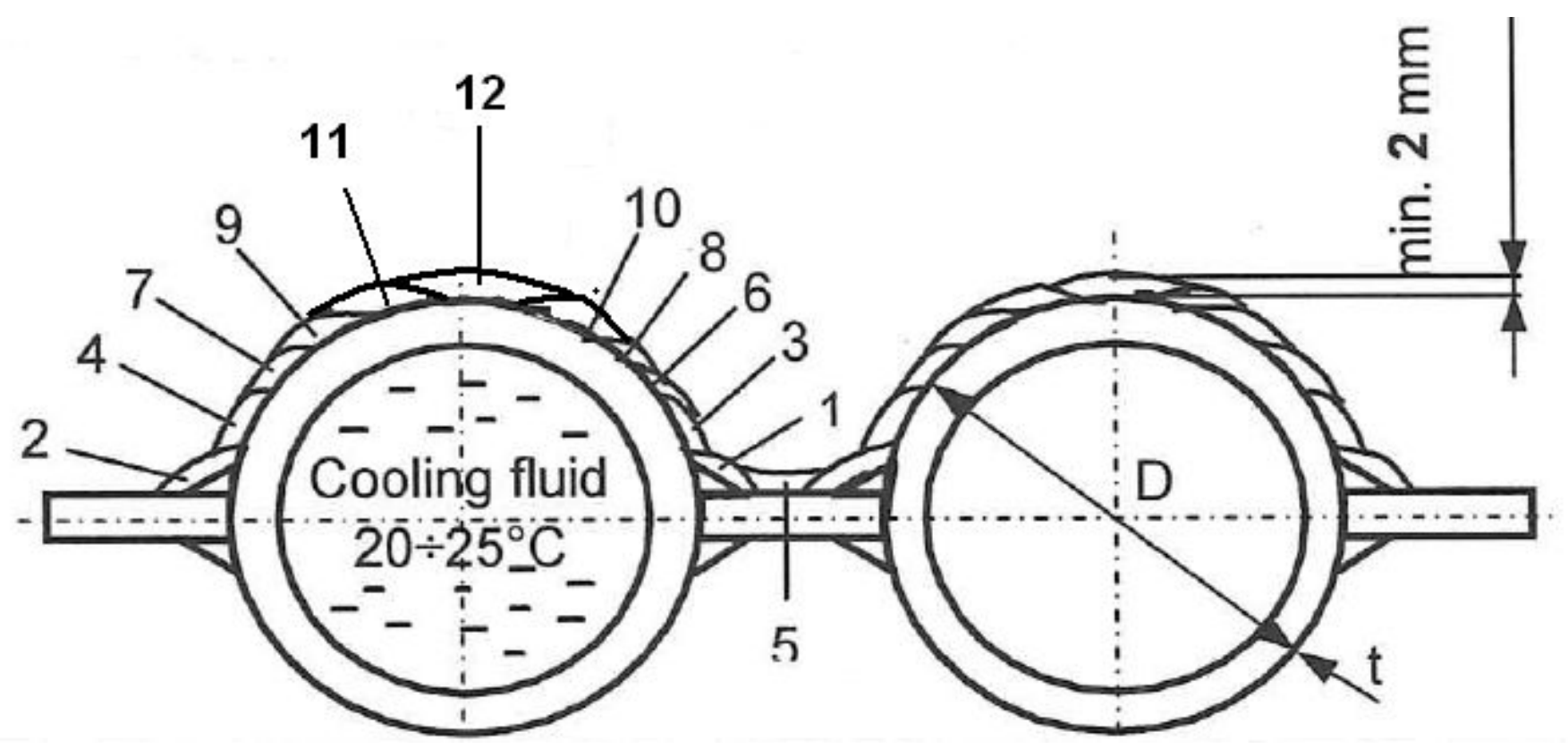

Figure 1 Sequence of cladding membrane tube wall in a vertical position [1]

Slika 1 Redosled navara cevi membranskog zida u vertikalnom položaju [1]

Kada se koriste parametri zavarivanja za četvorokomponentni gas $u$ kombinaciji sa dvokomponentnim zaštitnim gasom, pojavljuju se defekti (otvorene pore) na površini navara. Razlog za to je odsustvo inertnog gasa helijuma, koji poboljšava širenje šavova i obezbeđuje bolje "kvašenje " rastopljene kupke sa osnovnim materijalom i eliminaciju $\mathrm{H}_{2}$, što obezbeđuje veću brzinu navarivanja.

Zbog izbacivanja zaštitnih gasova $\mathrm{He}$ i $\mathrm{H}_{2}$, neophodno je smanjiti brzinu navarivanja ili brzinu dodavanja žice da bi se održavala približna debljina navarenih površina. Navarivanjem I podešavanjem parametara zavarivanja, može se uočiti razlika u širini pomeranja gorionika, brzini transporta žice i brzine zavarivanja pri korišćenju različitih zaštitnih gasova. Pri korišćenju dvokomponentnog zaštitnog
When using welding parameters for fourcomponent gas in combination with two-component protective gas, it comes to the appearance of defects (open pores) on the cladding surface. The reason for the appearance of defects is the lack of inert gas helium, which improves the spreading of welds and provides better "wetting" of melting baths with basic materials and elimination of $\mathrm{H}_{2}$, which provides a higher speed of cladding.

Due to the elimination of protective gases $\mathrm{He}$ and $\mathrm{H}_{2}$, it is necessary to reduce or decrease cladding speed and wire speed to maintain an approximate thickness of welded surfaces. By cladding and adjustment of welding parameters, one can see the difference in the width of the swinging burner, speed of wire transport and welding speed using different shielding gases. Using a two-component shielding gas it is necessary to expand the width of 
gasa, neophodno je povećati širinu pomeranja gorionika, jer zbog nedostatka gasa He ima malo tečenje. Zbog ekspanzije oscilovanja I nedostatka gasa $\mathrm{H}_{2} \mathrm{u}$ ovoj mešavini, potrebno je smanjiti brzinu zavarivanja jer $\mathrm{H}_{2}$ obezbeđuje veće brzine zavarivanja.

Ukupno smanjenje brzine zavarivanja je $15 \%$ brzine zavarivanja. Kako je sadržaj Fe na površini navara povećan, to je potrebno smanjiti količinu unete toplote preko jačine struje ili brzine transporta žice. the swinging burner, because of the lack of He gas has less spillage. Due to the expansion of oscillation and the lack of $\mathrm{H}_{2}$ gas in this mixture of gases is necessary to reduce the speed welding because the $\mathrm{H}_{2}$ provides greater speed welding.

Total reduction in welding speed is $15 \%$ of the welding speed. As the $\mathrm{Fe}$ content at the cladding surface weld beads is elevated it is necessary to reduce heat input over-current welding, or wirespeed transport.

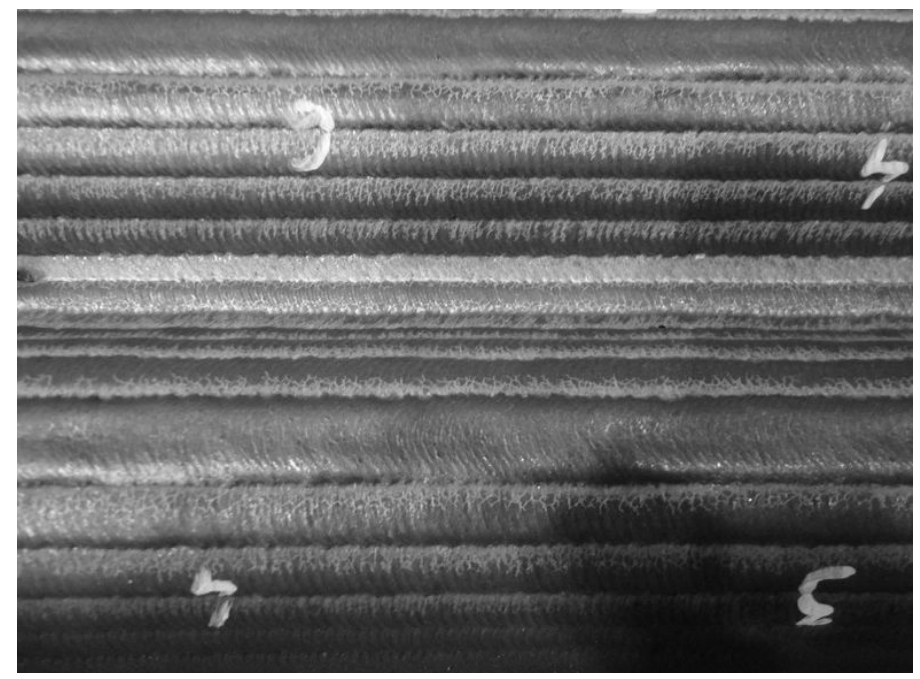

Figure 2 Pattern welded in the protection of the two-component gas.

Slika 2. Šablon navara u zaštiti dvokomponentnog gasa

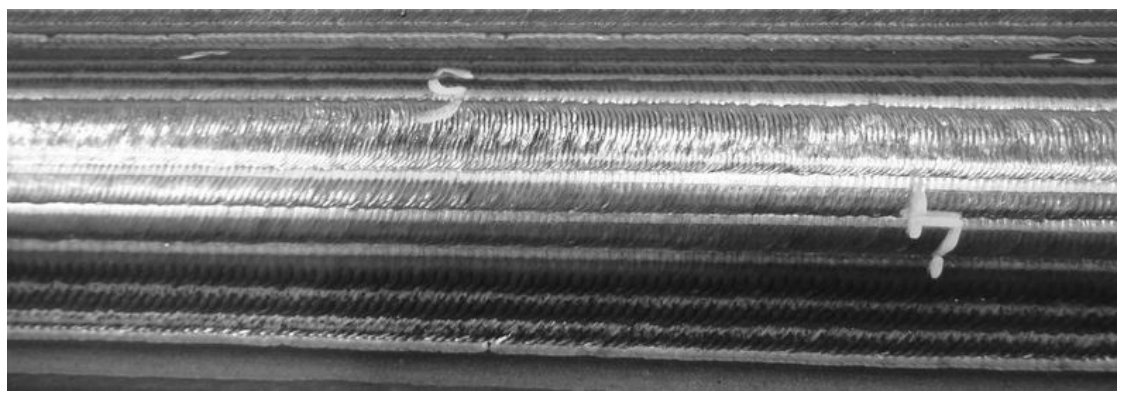

Figure 3 Pattern welded in the protection of the four-component gas Slika 3. Šablon navara u zaštiti četvorokomponentnog gasa

Rezultati navarenih uzoraka su navari izvedeni bez čađi i dima tokom zavarivanja. Površina navara je vizuelno grublja duž šava u pređenju sa četvorokomponenetnom mešavinom uz neprirodno tamne šavove (Slike 2 i 3). Iz tabele 1 vidi se da su

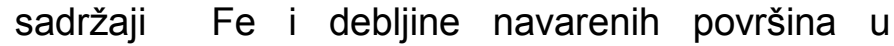
zahtevanim granicama. Kada uporedimo rezultate za debljinu i sadržaje Fe zavisno od zaštitnog gasa, može se zaključiti da je debljina navara koji sadrže $\mathrm{Fe}$ na površini skoro identična bez obzira na zaštitni gas.
Results of cladding samples are surface weld beads without soot and smoke during welding. Surface of weld beads is visually rougher crossings to weld compared to four-component mix and unnatural dark welds (Figure 2 and 3 ). From Table 1 one can see that the contents of $\mathrm{Fe}$ and the thickness of the weld surface are in the required limits. When we compare results of the thickness and contents of the Fe depending on the protective gas, it can be concluded that the thickness of the Fe-content of the weld beads on the surface is almost identical regardless of the shielding gas. 
Two-component gas/dvokomponentni gas

\begin{tabular}{|c|c|c|c|c|c|c|c|c|c|c|}
\hline & 1. & 2. & 3. & 4. & 5. & 6. & 7. & 8. & 9. & 10. \\
\hline $\mathrm{Fe}(\%)$ & 2,56 & 3,5 & 4,40 & 3,9 & 4,1 & 2,14 & 2,58 & 3,0 & 3,3 & 3,8 \\
\hline $\mathrm{d}(\mathrm{mm})$ & 3,3 & 2,97 & 2,43 & 2,73 & 3,0 & 3,10 & 2,80 & 2,6 & 3,5 & 3,2 \\
\hline
\end{tabular}

Four-component gas/ četvorokomponentni gas

\begin{tabular}{|c|c|c|c|c|c|c|c|c|c|c|}
\hline & 1. & 2. & 3. & 4. & 5. & 6. & 7. & 8. & 9. & 10. \\
\hline Fe (\%) & 3,0 & 3,53 & 3,0 & 3,2 & 3,1 & 2,95 & 2,8 & 3,3 & 3,9 & 3,8 \\
\hline $\mathrm{d}(\mathrm{mm})$ & 2,95 & 3,0 & 3,2 & 2,9 & 2,4 & 2,71 & 2,6 & 3,29 & 2,8 & 3,2 \\
\hline
\end{tabular}

Table 1. Measured values of thickness and content of Fe on vertical cladding

Tabela 1. Izmerene vrednosti debljine i sadržaja Fe pri vertikalnom navarivanju

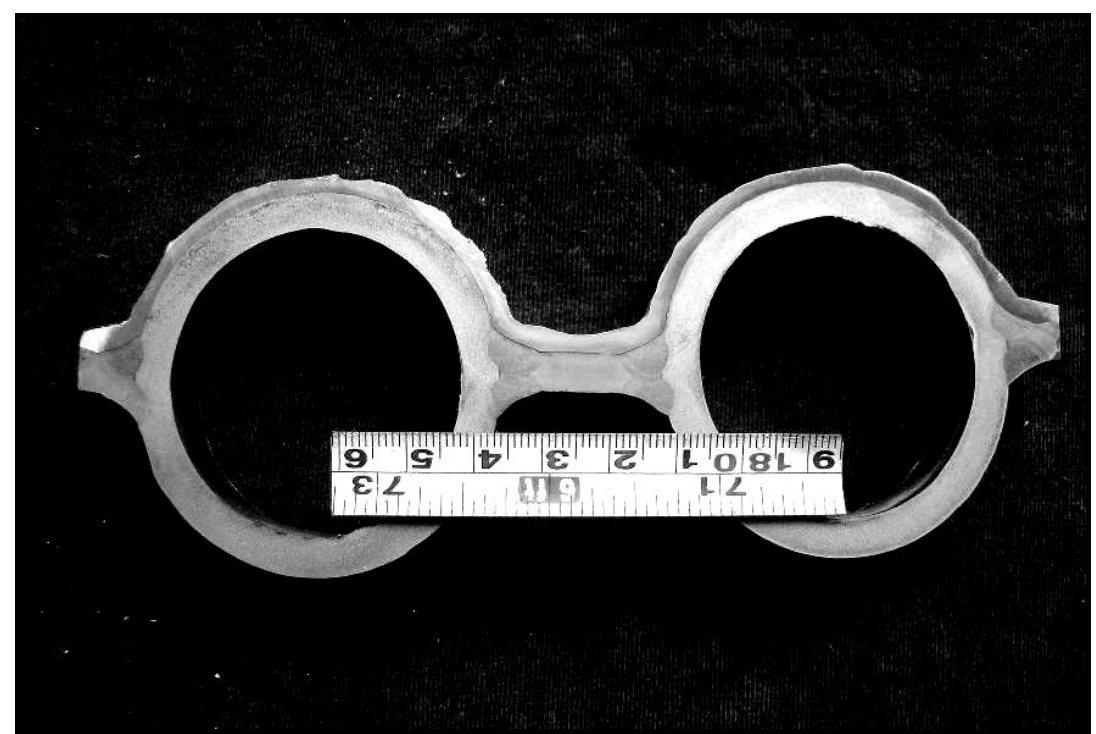

Figure 4. Cross section of cladded wall in vertical position in the protection of two-component gas [1]

Slika 4. Poprečni presek navarenog zida u vertikalnom položaju u zaštiti dvokomponentnog gasa [1]

\section{Optimizacija horizontalnog navarivanja}

Navarivanje je izvedeno uz pomoć robota za horizontalno navarivanje cevi membranskih zidova. Uzorci za navarivanje su identični membranskom zidu : membranska cev prečnika $\varnothing 57$ x 5,6, razmak između cevi $81 \mathrm{~mm}$, od osnovnog materijala kvaliteta $16 \mathrm{Mo} 3$, sa dodatnim materijalom Sandvik Sanicro 60, ERNiCrMo-3, GNi6625. Kao i u prethodnom pokušaju, prvi korak u navarivanju je definisanje parametara zavarivanja za četvorokomponentni gas.

Posle navarivanja uzoraka u zaštiti oba gasa, imamo rezultate u povećanju širine oscilacije I potrebnog smanjenja brzine navarivanja u zaštiti

\section{Optimization of the horizontal cladding}

Cladding was performed by the robot for cladding membrane tube walls. Cladding samples are identical to membrane wall: pipe diameter $\varnothing 57 \times 5,6$, peach between the tube $81 \mathrm{~mm}$, basic material 16Mo3, filler metal Sandvik Sanicro 60, ERNiCrMo3, GNi6625. As in the previous working trial, the first step of cladding is definition of the welding parameters for four-component gas.

After cladding samples in the protection of both gases we have results of increase of the width oscillation and necessary speed reduction of cladding in the protection of the two-component gas, in order to avoid the appearance of defects on 
dvokomponentnog gasa, u cilju izbegavanja prisustva defekata na površini šava. Pri zavarivanju u zaštititi dvokomponentnog gasa, povećanjem brzine transporta žice zadržava se generalna brzina zavarivanja, ali sadržaj $\mathrm{Fe}$ na površini navara ne zadovoljava kriterijume i udeli nadmašuju zahtevanih $5 \%$. Pri zavarivanju u dvokomponentnom gasu neophodno je smanjiti parametre zavarivanja, smanjiti struju zavarivanja (brzina transporta žice ) i smanjiti brzinu zavarivaja. the surface of the weld. By welding in protection of the two-component gas, increasing the speed of wire transport retain the overall speed of welding, but the content of $\mathrm{Fe}$ on the cladding surface does not meet the criteria and amounts over the required $5 \%$. By welding in the protection of two-component gas it is necessary to decrease the welding parameters, the reduction of welding current (wire speed transport) and reduce the speed of welding.

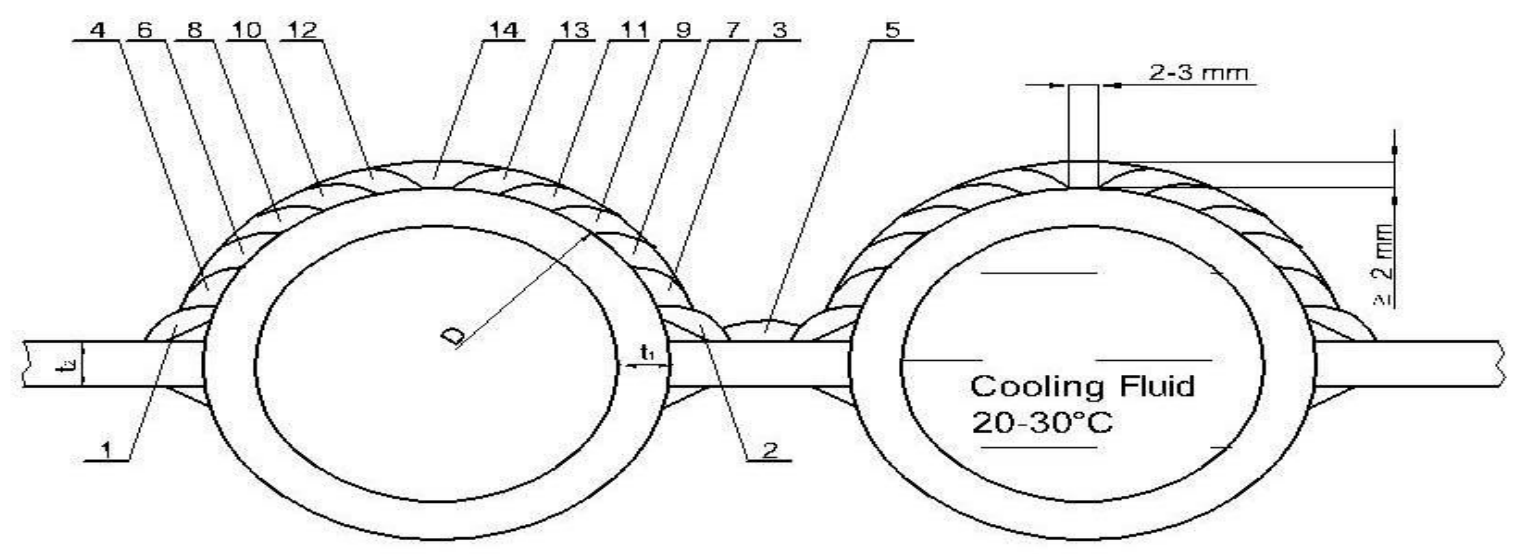

Figure 5. Sequence of cladding membrane tube walls in a horizontal position [1]

Slika 5. Redosled navara na cevima membranskog zida u horizontalnom položaju [1]

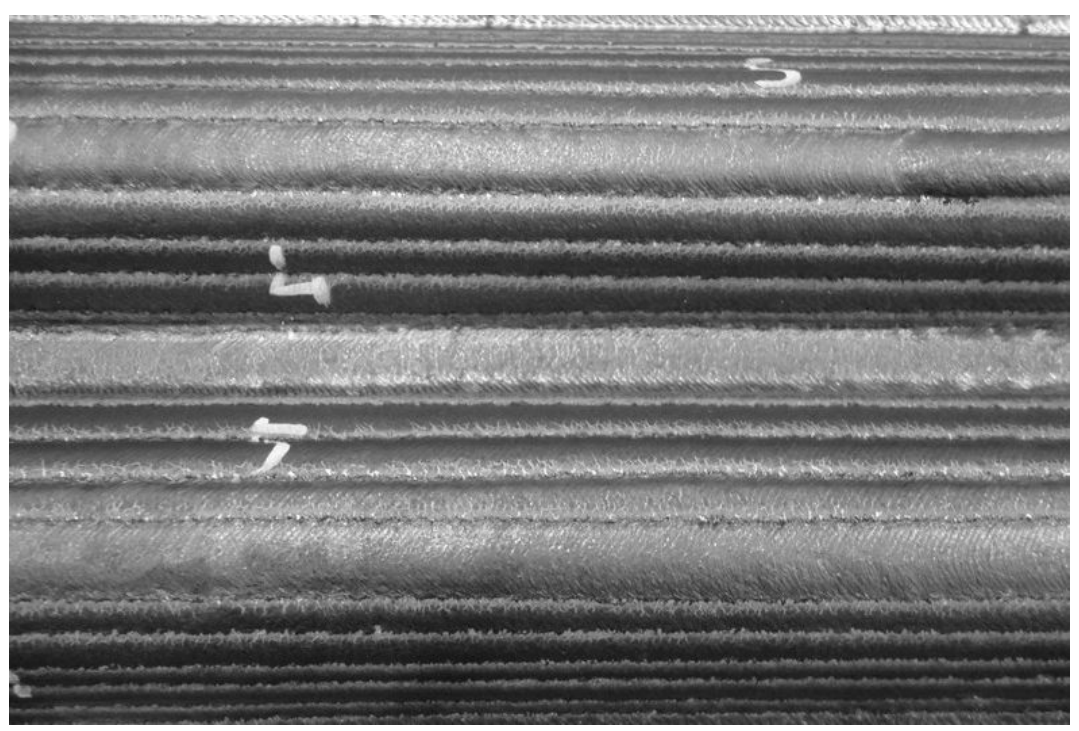

Figure 6. Sample welded in the protection of the two-component gas

Slika 6. Uzorak zavaren u zaštiti dvokomponentnog gasa 


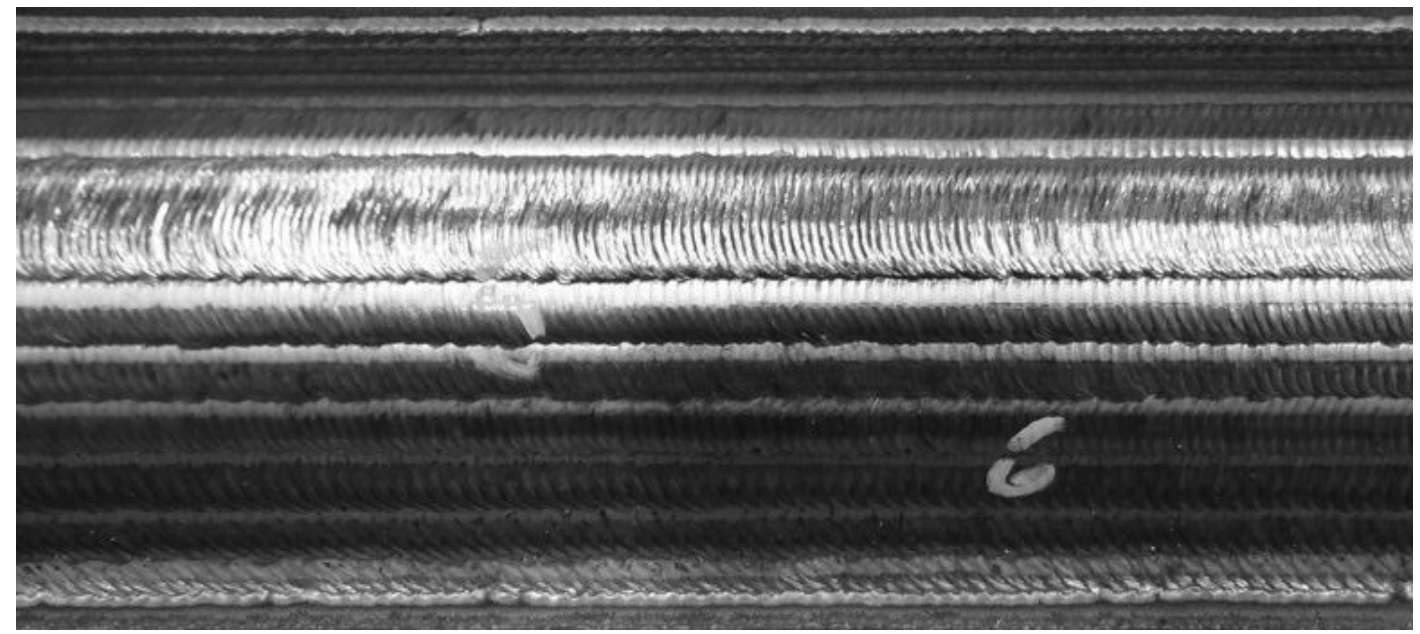

Figure 7. Sample welded in the protection of the four-component gas

Slika 7. Uzorak zavaren u zaštiti četvorokomponentnog gasa

Posle robotskog navarivanja uzorka, kao rezultat imamo površinu tamno plave boje sa ggrubim prelazima između navara (SI. 6 i 7).
After the robotic cladding sample for the results we have a dark blue color of the surface with a rough transitions weld beads (Fig. 6 and 7 ).

\begin{tabular}{|c|c|c|c|c|c|c|c|c|c|c|}
\hline \multicolumn{11}{|c|}{ Two-component gas/dvokomponentni gas } \\
\hline & 1. & 2. & 3. & 4. & 5. & 6. & 7. & 8. & 9. & 10. \\
\hline $\mathrm{Fe}(\%)$ & 1,92 & 1,94 & 2,05 & 2,09 & 1,98 & 3,00 & 2,97 & 1,35 & 2,05 & 1,65 \\
\hline $\mathrm{d}(\mathrm{mm})$ & 3,65 & 3,09 & 2,85 & 3,16 & 2,61 & 2,73 & 3,45 & 2,97 & 3,60 & 3,03 \\
\hline \multicolumn{11}{|c|}{ Four-component gas/četvorokomponentni gas } \\
\hline & 1. & 2. & 3. & 4. & 5. & 6. & 7. & 8. & 9. & 10. \\
\hline $\mathrm{Fe}(\%)$ & 0,5 & 0,8 & 1,3 & 1,4 & 1,1 & 0,9 & 0,7 & 0,3 & 1,2 & 1,9 \\
\hline $\mathrm{d}(\mathrm{mm})$ & 2,8 & 2,8 & 2,34 & 2,72 & 3,03 & 2,56 & 2,2 & 2,9 & 2,5 & 2,9 \\
\hline
\end{tabular}

Table 2. Measured values of thickness and content of Fe on horizontal cladding

Tabela 2. Izmerene vrednosti debljine i sadržaja Fe pri horizontalnom navarivanju

Prema tabeli 2. debljina navarene površine i sadržaj $\mathrm{Fe}$ su u zahtevanim granicama. Upoređenjem rezultata za debljinu i sadržaj Fe zavisno od zaštitnog gasa, može se zaključiti da je prosečna vrednost debljine navarene površine 0.4 $\mathrm{mm}$ veća na uzorku navarenom u zaštiti dvokomponentne mešavine, dok je sadržaj $\mathrm{Fe}$ prossečno za $1 \%$ veći, ali još uvek u zahtevanom opsegu.
From Table 2. the thickness of the weld surface and the $\mathrm{Fe}$ content is in the required limits. By comparing the results of thickness and content of $\mathrm{Fe}$ depending on the shielding gas it can be concluded that the average thickness of the cladding surface is $0.4 \mathrm{~mm}$ larger on sample cladding in protection of two-component mixtures, while the content of $\mathrm{Fe}$ is average of $1 \%$ higher, but still in the required range. 


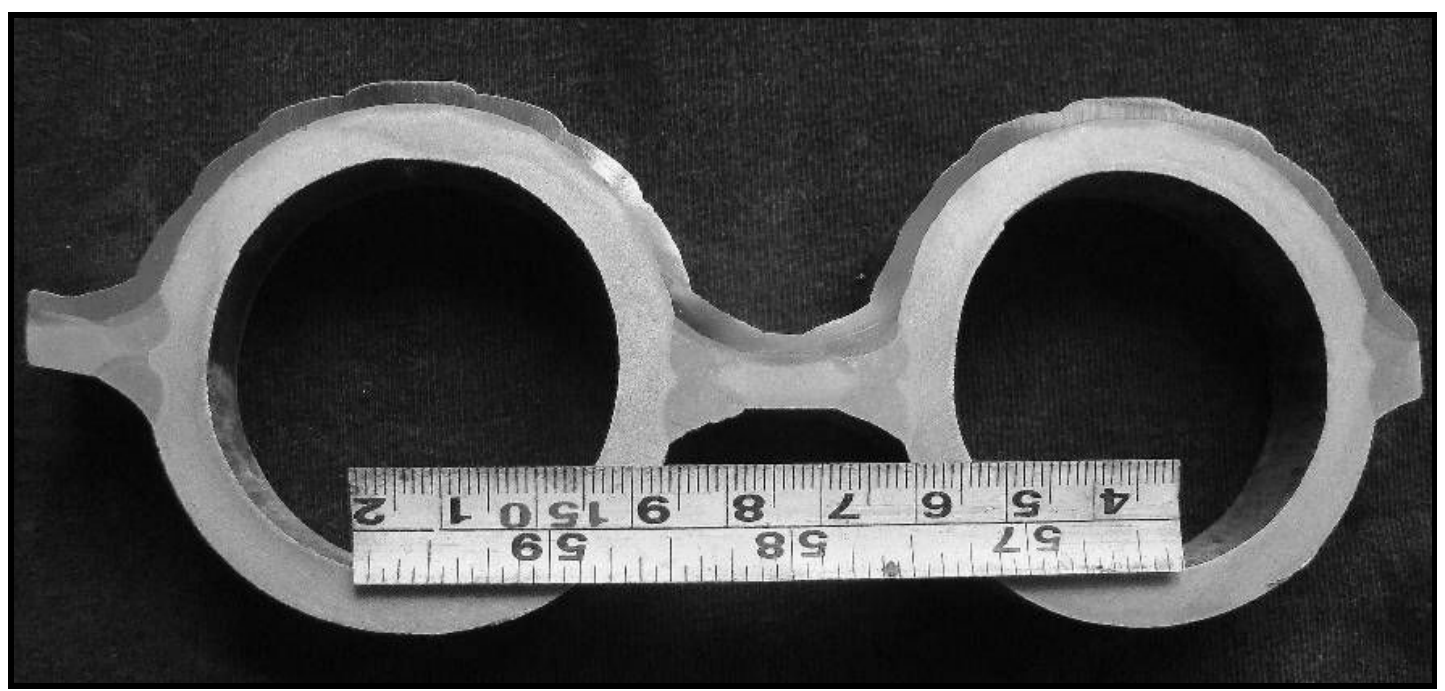

Figure 8. Cross section of cladded wall in horizontal position in protection of two-component gas [1]

Slika 8. Poprečni presek navarenog zida u horizontalnom položaju u zaštiti dvokomponentnog gasa [1]

\section{Optimizacija navarivanja pojedinačnih cevi}

Navarivanje je obavljeno uz pomoć mašine za navarivanje pojedinačnih cevi i zaglavaka. Zavareni uzorak je cev $\varnothing 57 x 5,6 \mathrm{~mm}$, dužine $300 \mathrm{~mm}$, osnovni materijal 16Mo3, dodatni materijal Sandvik Sanicro 60, ERNiCrMo-3, GNi6625.

\section{Optimization of the cladding for single tubes for window openings}

Cladding was done by a machine for the cladding of single tubes and headers. Welded sample is tube $\varnothing 57 \times 5,6 \mathrm{~mm}$, length $300 \mathrm{~mm}$, basic material 16Mo3, filler metal Sandvik Sanicro 60, ERNiCrMo3, GNi6625.

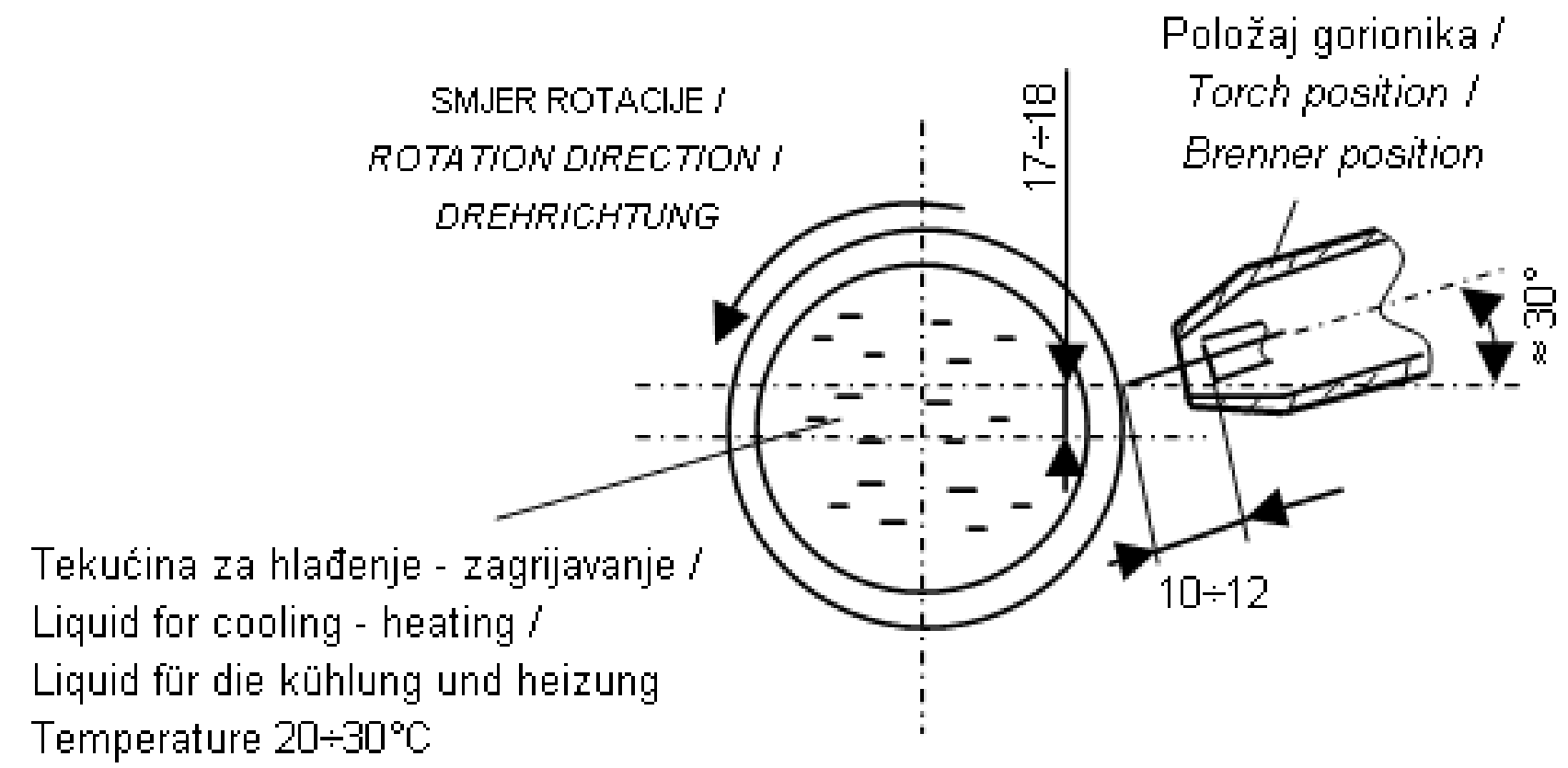

Figure 9. Position of cladding and direction of rotation of the single tubes [1]

Slika 9. Položaj navarivanja i pravac rotiranja pojedinačnih cevi [1] 
Navareni uzorci pojedinačnih cevi u zaštiti dvokomponentne i četvorokomponentne mešavine gasova, pokazuju da se brzina zavarivanja ne menja značajno pri korišćenju kombinacije različitih gasnih mešavina, dok se brzina žice (struja zavarivanja) smanjuje pri korišćenju dvokomponentnog zaštitnog gasa. Smanjenjem struje zavarivanja, smanjena je količina unete toplote u osnovni materijal i mešanje primarnih i dodatnih materijala to uzrokuje migraciju do nepoželjnog sadržaja Fe na površinu navara.
Cladding samples of the single tubes in protection of two-component and four-component mixtures of gases, shows that welding speeds are not significantly changed by using a combination of different gas mixtures, while the wire speed (welding current) is reduced by using twocomponent shielding gas. By reducing the welding current, it is reduced heat input into the base material and mixing of primary and supplementary materials and thus causes the migration of unwanted content of $\mathrm{Fe}$ on the surface of weld bead.

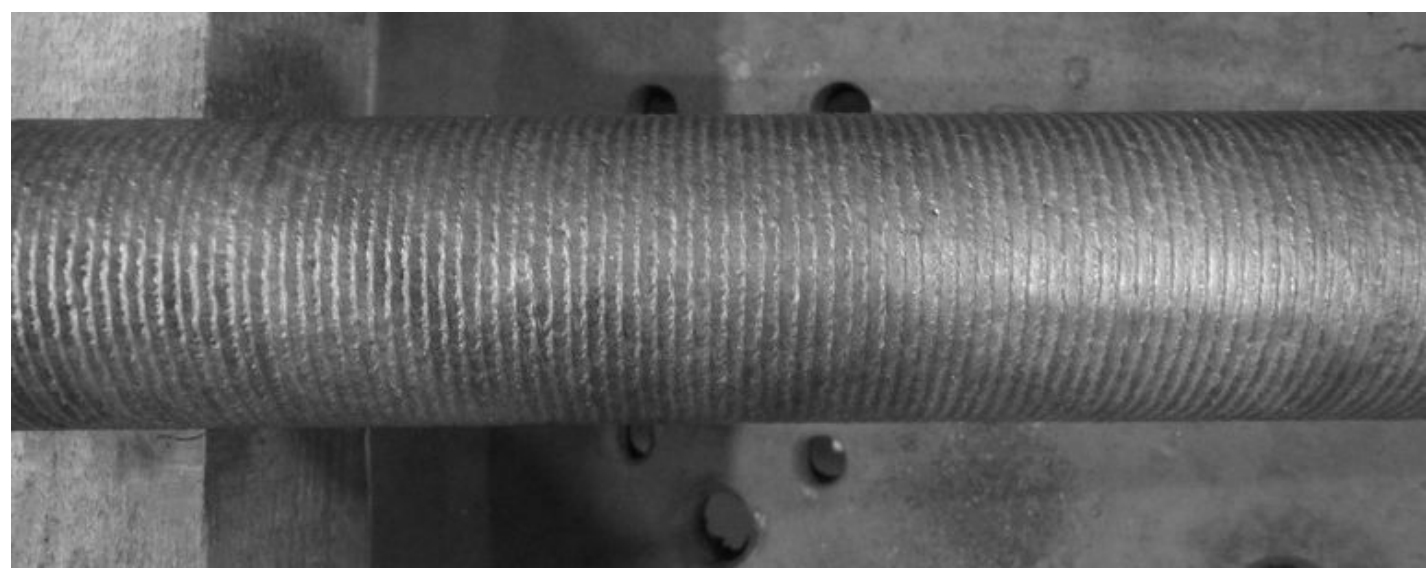

Figure 10. Sample welded in the protection of two-component gas

Slika 10. Uzorak zavaren u zaštiti dvokomonentnog gasa

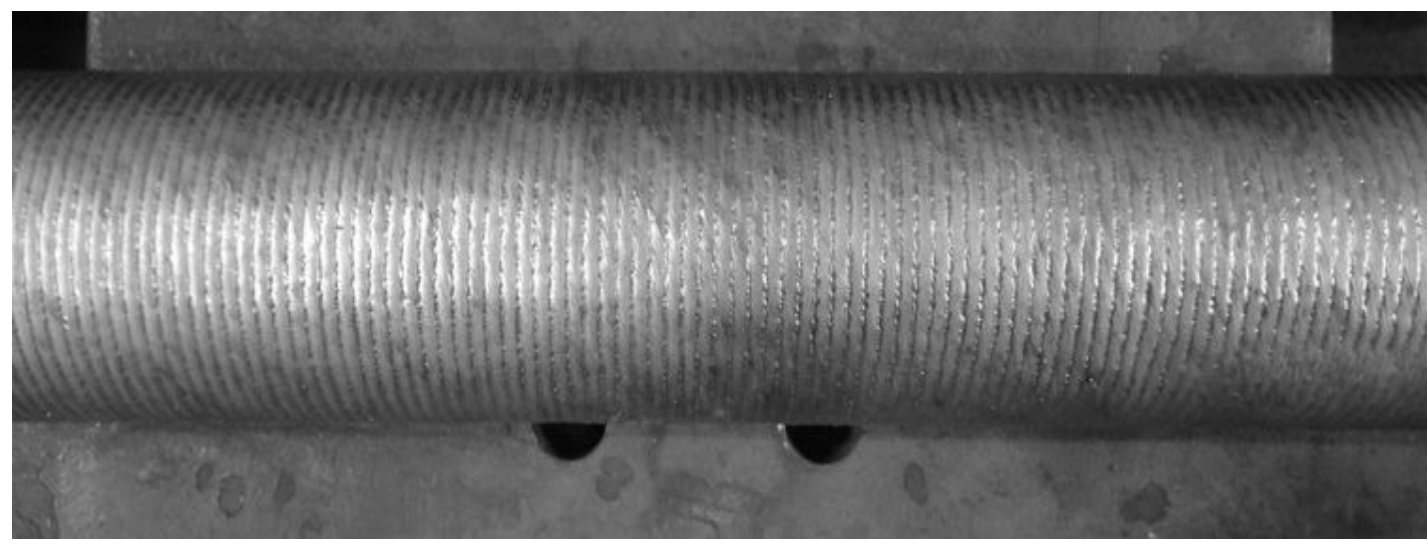

Figure 11. Sample welded in the protection of four-component gas

Slika 11. Uzorak zavaren u zaštiti četvorokomonentnog gasa

Upoređenjem sl. 10. i 11. Uočava se razlika u vizuelnom kvalitetu navarene površine. Rezultat navarenog uzorka za pojedinačne cevi u zaštiti dvokomponentnog gasa je: površina tamno plave boje sa lošim širenjem navara. Poršina navara je gruba i estetski inferiorna u odnosu na uzorak zavaren u zaštiti četvorokomponentne mešavine.
A comparison of Fig. 10. and 11. shows the difference in the visual quality of the cladding surface. The result of the cladding sample for single tubes in the protection of two-component mixtures of gases is: dark blue color of surface with a bad spreading transition of cladding. Surface of cladding is rough and aesthetically inferior to sample weld in protection of four-component mixture. 
Two-component gas/dvokomponentni gas

\begin{tabular}{|c|c|c|c|c|c|c|c|c|c|c|}
\hline & 1. & 2. & 3. & 4. & 5. & 6. & 7. & 8. & 9. & 10. \\
\hline Fe (\%) & 3,66 & 3,20 & 3,58 & 3,17 & 4,00 & 3,60 & 3,40 & 3,50 & 4,15 & 3,50 \\
\hline $\mathrm{d}(\mathrm{mm})$ & 2,36 & 2,27 & 2,39 & 2,29 & 2,24 & 2,34 & 2,26 & 2,26 & 2,27 & 2,19 \\
\hline
\end{tabular}

Four-component gas/četvorokomponentni gas

\begin{tabular}{|c|c|c|c|c|c|c|c|c|c|c|}
\hline & 1. & 2. & 3. & 4. & 5. & 6. & 7. & 8. & 9. & 10. \\
\hline Fe (\%) & 3,50 & 3,60 & 3,50 & 3,60 & 3,54 & 3,61 & 3,47 & 3,50 & 3,60 & 3,55 \\
\hline $\mathrm{d}(\mathrm{mm})$ & 2,47 & 2,53 & 2,48 & 2,53 & 2,49 & 2,57 & 2,51 & 2,47 & 2,53 & 2,51 \\
\hline
\end{tabular}

Table 3 Measured values of thickness and Fe content of a single tubes cladding

Tabela 3. Izmerene vrednosti debljine i sadržaja Fe pri navarivanju pojedinačnih cevi

Iz tabele 3. se može videti da su debljina navarene površine i sadržaj $\mathrm{Fe}$ na površini u zahtevanim granicama. Upoređenjem rezultata za debljinu i sadržaj Fe zavisno od zaštitnog gasa, zaključujemo da je debljina navara za $0.2 \mathrm{~mm}$ manja u zaštiti dvokomponentnog gasa, dok je sadržaj Fe sdkoro identičan.
From Table 3. we can see that the thickness of the cladding surface and the Fe content on surface are in the required limits. By comparing the results of thickness and content of $\mathrm{Fe}$ and depending on the protective gas, we conclude that the thickness of weld beads is $0.2 \mathrm{~mm}$ less in the protection of twocomponent gas, while the content of $\mathrm{Fe}$ is almost identical.

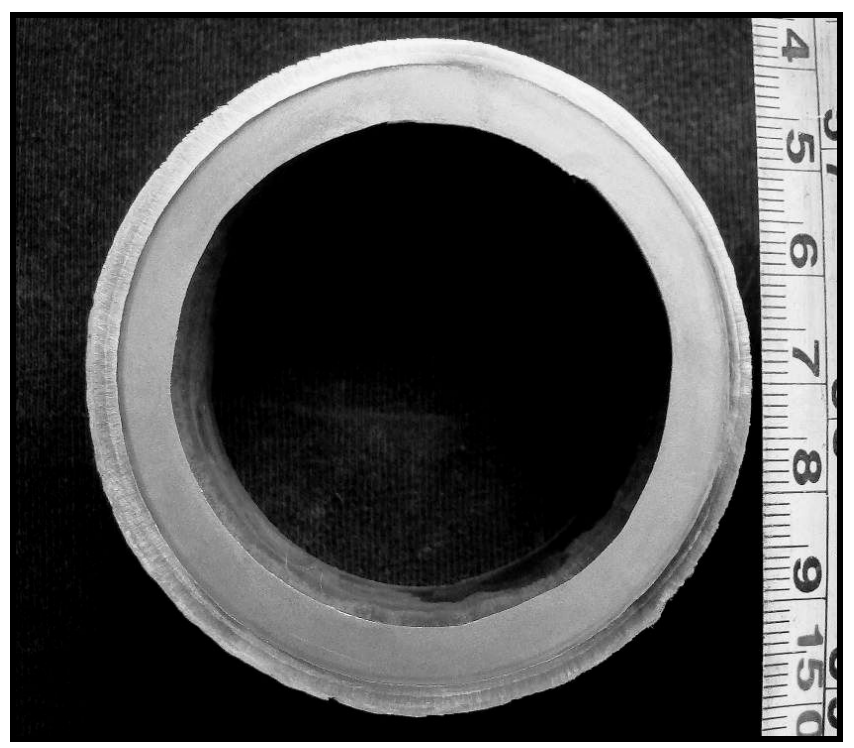

Figure 12. Cross section of cladded wall in horizontal position in protection of two-component gas Slika 12. Poprečni presek navarenog zida u zaštiti dvokomponentnog gasa 


\section{Upoređenje rezultata navarivanja u zaštiti dvokomponentne i četvorokomponentne mešavine gasova}

Četvorokomponentne mešavine

$(\mathrm{Ar}+0,05 \% \mathrm{CO} 2+30 \% \mathrm{He}+2 \% \mathrm{H} 2)$

Dobro širenje metalne kupke

Optimalna brzina navarivanja

Optimalna jačina struje $140 \mathrm{~A}$

Dobri rezultati kod horizontalnog i vertikalnog navaraivanja

Glatke površine slojeva na prelazima šava

Sjajna površina navara

Dvokomponentne mešavine $(97,5 \% \mathrm{Ar}+2,5 \% \mathrm{CO} 2)$

Malo širenje metalne kupke

Smanjena brzina navarivanja

Smanjena jačina struje (zbog prevelikog izdvajanja $\mathrm{Fe}$ )

Neizvesnost u horizontalnom navarivanju (visok Fe)

Grube površine slojeva na prelazima šava

Neprirodna tamno siva boja površine

\section{Zaključak}

Tokom mašinskog navarivanja radnih uzoraka radi poređenja dobijenih REZULTATA paralni uzorci su zavarivani u zaštiti dvokomponentnih i četvorokomponentnih gasnih mešavina. Rezultati variraju zavisno od mašine za zavarivanje, položaja zavarivanja i korišćenog zaštitnog gasa za navarivanje.

Oblik navara na horizontalnoj robotskoj liniji za cevi membranskih zidova zadovoljava potrebne kriterijume vezaneza debljinu navarene površine i

sadržaj Fe u navarima na površini, dok je estetski i vizuelni izgled mnogo gori i grublji u poređenju sa navarenim površianama u zaštitit četvorokomponentnih gasnih mešavina. Pri navarivanju u zaštitit dvokomponentnih gasnih mešavina potrebno je smanjiti brzinu navarivanja i jačinu struje. S obzirom da je postupak zavarivanja u horizontalnom položaju to dovodi do većeg mešanja primarnog sa dodatnim materijalima i čak uzrokuje migraciju do nepoželjnog sadržaja Fe na površini navara... Uz optimalnu korekciju ili smanjenje struje zavarivanja i brzine zavarivanja takođe se očekuje manji udeo $\mathrm{Fe}$ na površini navara.
4. Comparison of results cladding in protecting two-component and four-componentgas mixtures

Four-component mixtures

$(\mathrm{Ar}+0,05 \% \mathrm{CO} 2+30 \% \mathrm{He}+2 \% \mathrm{H} 2)$

Good spreading of metal bath

Optimal cladding speed

Optimal welding current 140A

Good results in horizontal and vertical cladding

Smooth surface layers on the crossings weld

Glossy surface of cladding

Two-component mixtures (97,5\% Ar+2,5\%CO2)

Less spreading of metal bath

Reduce the speed of cladding

Redicing the welding current (because of too much extraction of $\mathrm{Fe}$ )

Uncertainty in the horizontal surfacing (high Fe)

Rough surface layers on the crossings weld

Unnatural dark gray color of surface

\section{Conclusion}

During machine cladding of working samples to compare the obtained RESULTS parallel samples were welded in protection of two-component and four-component gas mixtures. The results vary depending on the machine for welding, welding position and used shielding gas for cladding.

Cladding pattern in the horizontal line of robots for tube membrane walls meets the necessary criteria in terms of thickness cladding surface and $\mathrm{Fe}$ content of a weld beads on the surface, while aesthetically and visual

surface appearance is much worse and rougher compared to the cladding surface in protection of four-component gas mixtures. Cladding in protection of two-component gas mixtures it is necessary to reduce cladding speed and welding current. As the welding process takes place in a horizontal position it leads to the greater mixing of primary and supplementary materials and thus causes the migration of unwanted content of Fe on the surface of weld beads... With optimal correction or reduction of welding current and welding speed it is also expected a smaller proportion of Fe-and surface weld beads. 
Rezultati dobijeni uz pomoć mašine za pojedinačno navarivanje cevi i vertikalno navarivanje membranskih zidova zadovoljavaju zahtevani kriterijum za debljinu površinskog sloja i sadržaj Fe na površini, dok su vizuelni uslovi površine lošeg kvaliteta sa lošim prelazima u odnosu na četvorokomponentne mešavine gasova. Brzina vertikalnog navarivanja je smanjena u poređenju sa navarivanjem u zaštiti četvorokomponentne mešavine gasova.

Izmenama gasa za zavarivanje u cilju postizanja finasijskih ušteda, pokazano je da navarivanje ima svoju cenu vezanu za brzinu i kvalitet navarivanja. Korišćenjem dvokomponentne mešavine gasova nije moguće postići vizuelno kvalitetne zavarene slojeve uz zadržavanje postojeće brzine zavarivanja. Pri smanjenju brzine zavarivanja, vizuelni izgled površine je taman sa grubim prelazima između šavova.

\section{Literatura}

[1] ĐĐ TEP, Technological instruction and WPS, Slavonski Brod 2014,Croatia

[2] Sandvik, Welding products, Sweden

[3] Linde AG, Industrial gases, Germany

[4] Messer Croatia Plin, Technical gases, Croatia
The results obtained by a machine for single tube cladding and vertical cladding of membrane walls meet the required criteria of thick surface layer and the content of $\mathrm{Fe}$ on the surface, while the visual surface condition of poor quality with poor spreading transition is in relation to four-component mixture of gases. Speed of vertical cladding is reduced compared to cladding in protection fourcomponent gas.

By changing the gas for welding in order to achieve financial savings of the cladding has its price in terms of speed and quality of the cladding. Using the two-component shielding gas it is not possible to achieve visual quality welded layer while retaining the existing speed welding. With decreasing welding speed the visual appearance of the surface is dark with a rough crossing welds.

\section{References}

[1] ĐĐ TEP, Technological instruction and WPS, Slavonski Brod 2014,Croatia

[2] Sandvik, Welding products, Sweden

[3] Linde AG, Industrial gases, Germany

[4] Messer Croatia Plin, Technical gases, Croatia 